\title{
Gd-based protein cage nanoparticles provide enhanced $r 1$ relaxivity and detect experimental atherosclerosis
}

Lars O Liepold ${ }^{1}$, Masaki Uchida ${ }^{* *}$, Md Joynald Abedin ${ }^{1}$, Shefah Qazi ${ }^{1}$, Hisanori Kosuge ${ }^{2}$, Toshiro Kitagawa², Michael V McConnell ${ }^{2}$, Trevor Douglas ${ }^{1}$

From 2011 SCMR/Euro CMR Joint Scientific Sessions

Nice, France. 3-6 February 2011

\section{Objective}

Develop a highly sensitive T1 contrast agent based on chemically attaching a multitude of chelated Gd molecules constrained within a protein cage structure.

\section{Background}

A T1 nanoparticle contrast agent showing high $\mathrm{r} 1$ relaxivity is desired to provide more sensitive molecular/ cellular imaging with reduced $\mathrm{Gd}$ dose, and may have more clinical utility than $\mathrm{T} 2$ * (e.g., iron-based) approaches. Tethering multiple Gd-chelates to a supramolecular platform is a promising strategy to increase r1 relaxivity, as rotational correlation time of the $\mathrm{Gd}$ ions can become significantly larger which is highly favorable for efficient $\mathrm{r} 1$ relaxivity. Here we utilize a small heat shock protein cage (Hsp) with a $12 \mathrm{~nm}$ exterior diameter and a $9 \mathrm{~nm}$ interior cavity, as a platform to anchor Gd-DTPA.

\section{Methods}

1) Material development and evaluation

Hsp was purified from an E. coli expression system. An azide-alkyne based click reaction is cycled to produce a branched polymer network in the interior of the protein cage (Fig 1). The polymer results in a stable network containing Gd-DTPA, as the azide-containing monomer has the Gd chelate attached prior to polymer generation.

2) In vivo imaging of vascular inflammation

FVB mice underwent left carotid ligation after 4 weeks of high-fat diet and diabetes induction by streptozotocin. Two weeks later, Hsp-Gd or Magnevist (Gd-DTPA)

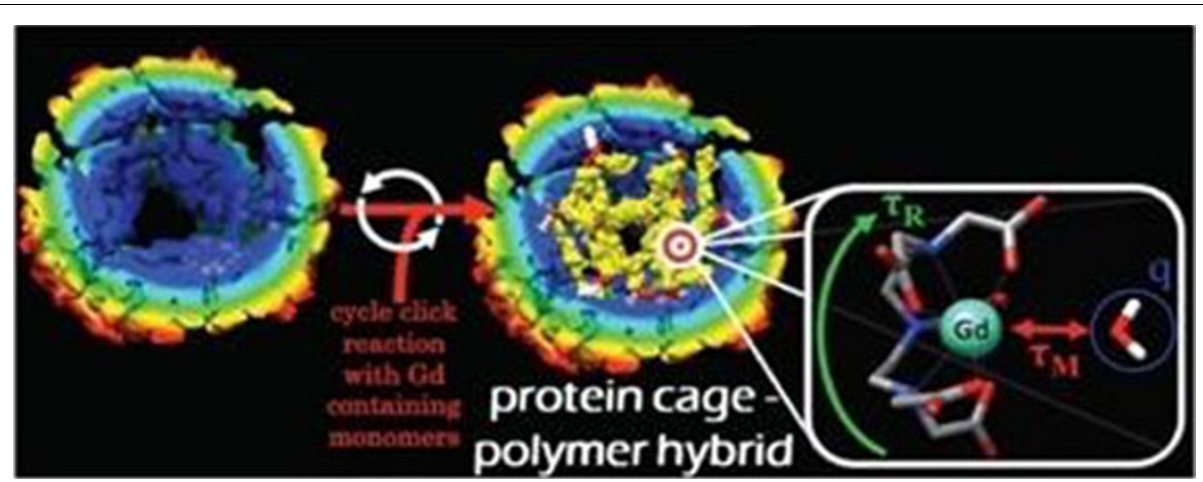

Figure 1 Illustration of Hsp-brach polymer with Gd.

'Montana State University, Bozeman, MT, USA

Full list of author information is available at the end of the article

(C) 2011 Liepold et al; licensee BioMed Central Ltd. This is an open access article distributed under the terms of the Creative Commons 


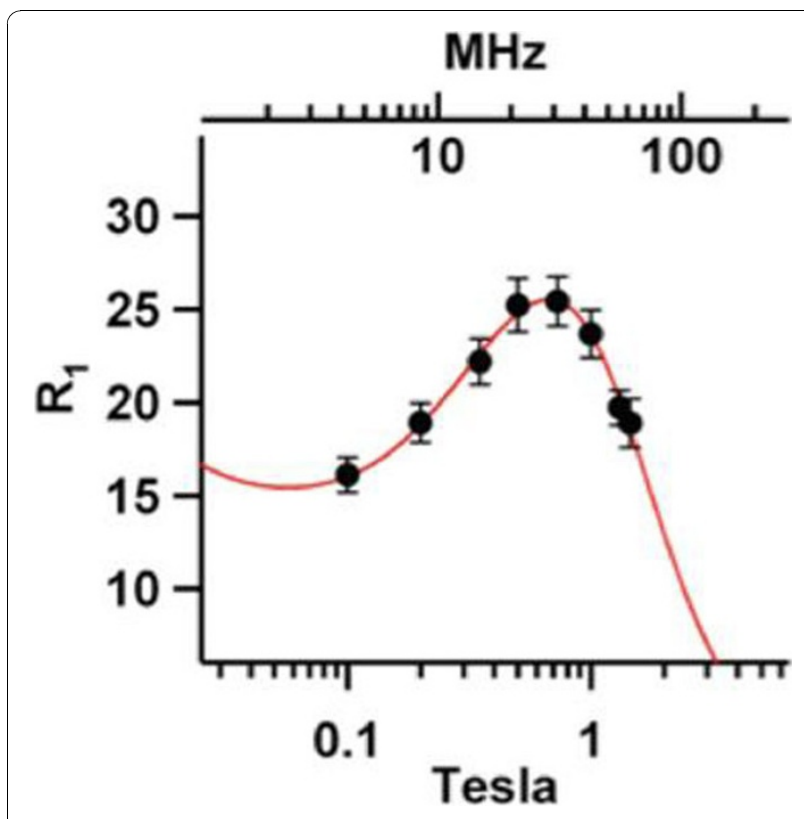

Figure 2 Graph of $r 1$ measurement at varying field.

was intravenously injected at a dose of $20 \mu \mathrm{mol} \mathrm{Gd} / \mathrm{kg}$ (one-fifth the typical clinical dose). Mice were imaged on a whole-body $3 \mathrm{~T}$ MRI scanner (Signa HDx, GE Healthcare) with a $50 \mathrm{mT} / \mathrm{m}, 150 \mathrm{~T} / \mathrm{m} / \mathrm{s}$ gradient system and a phased array mouse coil (RAPID MR International), using a T1-weighted fast spin echo sequence $(\mathrm{TR} / \mathrm{TE}=400 \mathrm{~ms} / 15 \mathrm{~ms}$, slice thickness $=1 \mathrm{~mm}$, FOV $=3 \mathrm{~cm}$, matrix $=256 \times 256$ ) before injection and $4 \mathrm{~h}$ after injection.

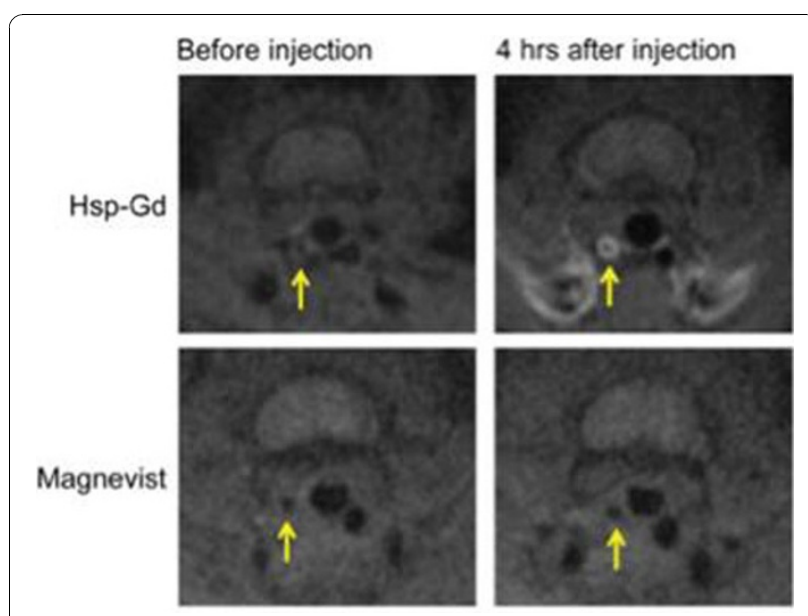

Figure 3 T1-weighted FSE MRI of ligated left carotids in mice before and after injection of Hsp-Gd (top) or Magnevist (bottom). The macrophage-rich left carotid lesion was clearly enhanced by Hsp-Gd, but not in the non-ligated right carotid artery or either carotid artery after Magnevist injection.

\section{Results}

In vitro analysis of Hsp-Gd showed about $160 \mathrm{Gd}$ DTPA molecules per cage. At $0.73 \mathrm{~T}$, the ionic (per Gd) $\mathrm{r} 1$ value is $25 \mathrm{mM}^{-1} \mathrm{sec}^{-1}$ and the particle $\mathrm{r} 1$ value is $4,200 \mathrm{mM}^{-1} \sec ^{-1}$ (Fig 2). At 3T, the ionic and particle $\mathrm{r} 1$ values are $9.7 \mathrm{mM}^{-1} \mathrm{sec}^{-1}$ and $1600 \mathrm{mM}^{-1} \mathrm{sec}^{-1}$, respectively. The ionic $r 1$ value is nearly 3 times higher than that of Magnevist. The macrophage-rich left carotid lesion, but not the non-ligated right carotid, was clearly detected on T1-weighted MR imaging 4h after injection of Hsp-Gd, whereas the same lesion was hardly detected after Magnevist injection (Fig. 3).

\section{Conclusion}

Gd can be effectively incorporated into polymer-incorporated protein cage nanoparticles providing high $\mathrm{r} 1$ relaxivity. Hsp-Gd allows positive contrast imaging of macrophage-rich carotid atherosclerosis with low $\mathrm{Gd}$ dosing. Thus, Gd-based protein cages are promising atherosclerosis imaging agents.

\section{Author details}

${ }^{1}$ Montana State University, Bozeman, MT, USA. ${ }^{2}$ Stanford University, Stanford, CA, USA.

Published: 2 February 2011

doi:10.1186/1532-429X-13-S1-P370

Cite this article as: Liepold et al:: Gd-based protein cage nanoparticles provide enhanced $\mathrm{r} 1$ relaxivity and detect experimental atherosclerosis. Journal of Cardiovascular Magnetic Resonance 2011 13(Suppl 1):P370.
Submit your next manuscript to BioMed Central and take full advantage of:

- Convenient online submission

- Thorough peer review

- No space constraints or color figure charges

- Immediate publication on acceptance

- Inclusion in PubMed, CAS, Scopus and Google Scholar

- Research which is freely available for redistribution
Bïmed Central 